\title{
PERUBAHAN ABNORMAL RETURN DAN VOLUME PERDAGANGAN PADA HARI SEKITAR CUM-DIVIDEND DATE DI BURSA EFEK INDONESIA
}

\author{
Eka Lavista \\ Fakultas Ekonomi dan Bisnis Universitas Jember \\ ekalavista@gmail.com \\ Elok Sri Utami \\ Fakultas Ekonomi dan Bisnis Universitas Jember \\ elok_utami@yahoo.co.id \\ Novi Puspitasari \\ Fakultas Ekonomi dan Bisnis Universitas Jember \\ novipuspitasari@unej.ac.id
}

\begin{abstract}
The purpose of this study is to examine the changes of the stock prices and stock volume traded on the Indonesia Stock Exchange (IDX) on the last day where the shareholders would still posses the right to dividends (cum-dividend date). The population of this study was all public companies listed in the IDX in 2013 that distributed their dividends continuously from 2014 to 2016. The sample consisted of 118 companies collected by using purposive sampling approach. The results showed that there was a difference of abnormal return and trading volume activity on the days around the cum-dividend date.
\end{abstract}

Keywords: dividen, cum-dividend date, abnormal return, trading volume activity, event study.

\begin{abstract}
Abstrak: Tujuan penelitian ini adalah untuk menganalisis perubahan harga saham dan volume saham yang diperdagangkan di Bursa Efek Indonesia (BEI) pada hari terakhir dimana pemegang saham masih akan berhak atas dividen (cum-dividend date). Populasi penelitian ini adalah seluruh perusahaan go public pada tahun 2013 yang terdaftar di BEI yang membagikan dividen secara terus menerus pada tahun 2014 sampai 2016. Sampel penelitian terdiri dari 118 perusahaan yang diambil dengan pendekatan purposive sampling. Hasil penelitian menunjukkan bahwa terdapat perbedaan abnormal return dan trading volume activity pada harihari sekitar cum-dividend date.
\end{abstract}

Kata kunci: dividen, cum-dividend date, abnormal return, trading volume activity, event study.

\section{Pendahuluan}

Pasar modal merupakan salah satu tempat yang dapat digunakan bagi investor untuk menginvestasikan sebagian dana yang mereka miliki. Secara umum pasar modal dapat diartikan sebagai suatu sistem keuangan yang terorganisasi, di dalamnya termasuk bank-bank komersial dan semua lembaga keuangan lainnya serta keseluruhan surat-surat berharga yang beredar. Dalam arti sempit, pasar modal adalah suatu pasar yang disiapkan untuk memperdagangkan saham, obligasi dan jenis surat berharga lainnya menggunakan jasa perantara pedagang efek (Sunariyah, 2000:4). Pasar modal, yang dikenal juga dengan sebutan bursa efek, menjadi sarana 
transaksi perdagangan saham antar investor dan berperan juga sebagai penunjang pengembangan perusahaan-perusahaan untuk mendapatkan sumber pendanaan melalui penjualan saham.

Pasar modal menjadi media bagi pihak yang kelebihan dana (investor atau calon pemegang saham) dan kekurangan dana (perusahaan). Investor dapat membeli saham di pasar perdana dan pasar sekunder. Perusahaan dapat menjual saham baru atau menjual saham yang sudah ditempatkan dan disetor penuh, dikenal dengan sebutan pencatatan saham perusahaan (company listing). Investor di pasar modal berharap untuk mendapatkan capital gain (keuntungan jual beli saham) dan dividen atas kepemilikan saham.

Proses penetapan atau keputusan pembayaran dividen tidak selalu sama antar perusahaan bahkan antar negara. Berbeda dengan di negara-negara barat dimana besar kecilnya dividen ditetapkan oleh manajemen, di Indonesia keputusan besar kecilnya dividen ditetapkan dalam rapat umum pemegang saham. Perbedaan ini membawa konsekuensi pada respon investor dimana ketidakpastian terkait dengan membagi atau tidak membagi di negera barat lebih tinggi daripada di Indonesia. Investor di Indonesia tidak terlalu besar menghadapi ketidakpastian tentang dividen karena besarannya diketahui pada saat rapat umum pemegang saham.

Perusahaan dengan imbal hasil dividen yang tinggi secara teori akan memiliki tingkat pengembalian atas investasi yang tinggi daripada perusahaan dengan imbal hasil dividen rendah. Hal ini terjadi karena investor harus membayar pajak atas dividen yang tinggi sementara pajak atas capital gain dapat ditunda sampai dengan benar-benar diterimanya capital gain. Hasil penelitian empiris masih belum konklusif, karena ada perbedaan di antara keduanya. Aharony dan Swary (1980) melaporkan bahwa perusahaan yang mengumumkan adanya kenaikan dividen akan mengalami kenaikan harga saham yang tercermin dari perubahan cumulative abnormal returnnya dan segitu sebaliknya.

Dividen sebagai sebuah sinyal akan menjadi alasan bagi perusahaan untuk menunjukkan kemampuan keuangan dan prestasi kerjanya. Sinyal akan berhasil apabila yang dilakukan oleh perusahaan dengan kinerja bagus melalui pembagian dividen tidak dapat diikuti oleh pesaingnya. Investor dengan orientasi capital gain berharap bahwa harga saham perusahaan yang membagi dividen akan naik. Jika harga saham naik, investor tidak hanya memperoleh capital gain, tetapi juga 
memperoleh dividen tunai jika masih memegang saham perusahaan maksimal sampai dengan hari dimana saham tidak berdividen (ex-dividend date).

Penelitian di Indonesia tentang efek perubahan dividen terhadap harga saham menunjukkan hasil bervariasi. Misalnya, Siaputra dan Atmadja (2006) menemukan adanya perbedaan harga saham antara sebelum dan sesudah ex-dividend date. Firmansyah dan Violita (2007) juga menemukan yang sama bahwa pasar bereaksi terhadap pengumuman saham, khususnya di hari ex-dividend date. Sedangkan Winarno (2006) tidak menemukan adanya reaksi positif pasar atas pengumuman kenaikan dividen dalam bentuk tidak adanya kenaikan harga yang signifikan.

Penelitian atas respon pasar terhadap kebijakan dividen sejauh ini lebih diarahkan pada ada tidaknya abnormal return di hari atau tanggal pengumuman dividen. Penelitian yang secara khusus mengkaji perubahan harga saham dan volume saham yang diperdagangkan pada hari terakhir dimana pemegang saham masih akan berhak atas dividen (cum-dividend date) belum banyak dilakukan. Tujuan penelitian ini adalah: (1) menganalisis perbedaan abnormal return saham antara sebelum, saat dan sesudah cum-dividend date; (2) Menganalisis perbedaan volume perdagangan saham antara sebelum, saat dan sesudah cum-dividend date.

\section{Metodologi}

Penelitian ini merupakan penelitian deskriptif kuantitatif yang mencoba menjelaskan secara deskriptif perubahan-perubahan nilai variabel-variabel penelitian dengan pengujian atas hipotesis yang diajukan. Penelitian jenis ini termasuk kedalam penelitian kuantitatif. Periode estimasi analisis data ditunjukkan pada Gambar 1. berikut.

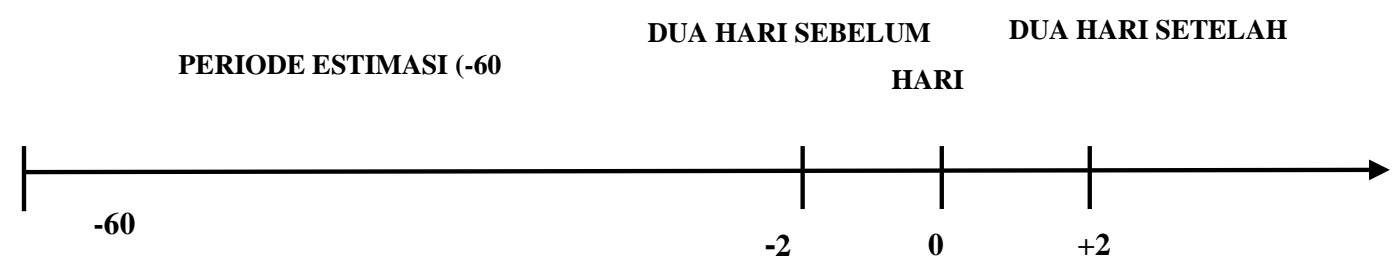

Gambar 1. Periode Estimasi Penelitian

Sumber: Gumanti (2013), dimodifikasi

Populasi penelitian ini adalah semua perusahaan yang membagikan dividen tunai tahun 2014 sampai 2016 merupakan populasi penelitian ini, hal ini berarti mencakup tiga tahun analisis. Sampel penelitian ditetapkan dengan metode 
purposive sampling. Kriteria untuk menetapkan sampel penelitian adalah sebagai berikut.

1. Perusahaan harus sudah menjadi perusahaan publik tahun 2013. Hal ini ditetapkan guna menghindari bias pada besaran dividen pada saat sebelum penawaran saham perdana (initial public offerings $=I P O$ ) dibandingkan dengan setelah IPO.

2. Perusahaan harus membagikan dividen secara terus menerus selama tiga tahun analisis. Hal ini disyaratkan untuk mendapatkan konsistensi dalam penilaian pasar.

3. Saham perusahaan yang membagi dividen harus likuid dengan kriteria setidaknya ditransaksikan minimal sebanyak 100 kali dalam satu tahun. Hal ini ditetapkan untuk menghindari bias atas saham-saham yang tidak ditransaksikan secara rutin (saham tidur).

Variabel utama penelitian ada dua, yaitu Abnormal return dan volume perdagangan saham. Abnormal return yaitu selisih antara tingkat keuntungan yang sebenarnya dengan tingkat keuntungan yang diharapkan. Volume perdagangan saham adalah jumlah lembar saham yang diperdagangkan dalam satu hari dibandingkan dengan jumlah saham beredar.

Semua variabel penelitian diukur dengan menggunakan skala rasio. Skala rasio yang dimaksud dinyatakan dalam persentase untuk variabel perubahan harga saham (abnormal return saham) dan volume perdagangan saham.

Analisis data yang digunakan untuk menjawab tujuan penelitian berturut-turut diuraikan sebagai berikut

1. Statistika Deskriptif

Pada penelitian ini, data akan dideskripsikan untuk mendapatkan gambaran tentang pola atau pergerakan data pada masing-masing variabel penelitian.

2. Uji beda rata-rata (t-test for mean difference)

Uji beda rata-rata digunakan untuk menguji hipotesis jika data penelitian memiliki distribusi normal. Uji ini digunakan untuk mengetahui ada abnormal return dan perubahan volume saham yang diperdagangkan pada hari-hari di sekitar Cumdividend date dan apakah terdapat perbedaan return saham di hari-hari sekitar cumdividend.

3. Uji beda median dengan uji Wilcoxon (Wilcoxon test for median) 
Uji Wilcoxon digunakan untuk mengetahui ada tidaknya perbedaan return saham di hari-hari sekitar cum-dividend. Uji Wilcoxon juga dilakukan untuk menguji hipotesis atas ada tidaknya perubahan volume saham yang diperdagangkan di sekitar hari cum-dividend.

Hipotesis Pertama dan Kedua penelitian akan dijawab dengan uji beda ratarata atas abnormal return saham saat cum-dividend date dan sesudah cum-dividend date apabila distribusi datanya adalah normal. Jika distribusi data penelitian tidak normal, maka pengujian hipotesis dilakukan dengan uji beda median (Wilcoxon signed-rank test) untuk hipotesis Pertama dan Kedua.

\section{Hasil dan Pembahasan}

$\underline{\text { Hasil }}$

Tabel 1. Statistik Deskriptif Abnormal return di Hari-hari Sekitar Cum-dividend

\begin{tabular}{ccccccc}
\hline No & Keterangan & Mean & Median & Minimum & Maksimum & $\begin{array}{c}\text { Dev. } \\
\text { Stand. }\end{array}$ \\
\hline \multicolumn{7}{c}{ Panel A. Tahun 2015 } \\
1 & Hari Minus 2 & 0,0053 & 0,0027 & $-0,0451$ & 0,0789 & 0,0185 \\
2 & Hari Minus 1 & $-0,0006$ & $-0,0005$ & $-0,0904$ & 0,1302 & 0,0224 \\
3 & Cum-dividend date & 0,0023 & $-0,0002$ & $-0,0525$ & 0,1113 & 0,0209 \\
4 & Hari Plus 1 & $-0,0117$ & $-0,0068$ & $-0,1920$ & 0,1036 & 0,0333 \\
5 & Hari Plus 2 & 0,0025 & 0,0004 & $-0,0513$ & 0,0678 & 0,0216 \\
\hline \multicolumn{7}{c}{ Panel B. Tahun 2016 } \\
\hline 1 & Hari Minus 2 & 0,0072 & 0,0006 & $-0,0934$ & 0,1897 & 0,0317 \\
2 & Hari Minus 1 & 0,0053 & 0,0004 & $-0,0551$ & 0,2337 & 0,0296 \\
3 & Cum-dividend date & $-0,0002$ & $-0,0002$ & $-0,0784$ & 0,0440 & 0,0196 \\
4 & Hari Plus 1 & $-0,0121$ & $-0,0067$ & $-0,1002$ & 0,1109 & 0,0315 \\
5 & Hari Plus 2 & $-0,0047$ & $-0,0017$ & $-0,1008$ & 0,0629 & 0,0235 \\
\hline
\end{tabular}

Sumber: diolah

Nilai rata-rata abnormal return positif pada hari cum-dividend untuk data tahun 2015 menyiratkan bahwa secara rata-rata investor memperoleh keuntungan pada hari cum-dividend. Hal yang sebaliknya terjadi untuk data tahun 2016, dimana nilai rata-rata abnormal return pada hari cum-dividend justru negative. Artinya, pada hari itu, secara rata-rata investor mengalami kerugian. 
Tabel 2. Statistik Deskriptif Volume Perdagangan Saham di Hari-hari Sekitar Cumdividend

\begin{tabular}{ccccccc}
\hline No & Keterangan & Mean & Median & Minimum & Maksimum & $\begin{array}{c}\text { Dev. } \\
\text { Stand. }\end{array}$ \\
\hline \multicolumn{7}{c}{ Panel A. Tahun 2015 } \\
1 & Hari Minus 2 & 0,0010 & 0,0003 & 0,0000 & 0,0216 & 0,0024 \\
2 & Hari Minus 1 & 0,0013 & 0,0004 & 0,0000 & 0,0378 & 0,0037 \\
3 & Cum-dividend date & 0,0013 & 0,0005 & 0,0000 & 0,0165 & 0,0026 \\
4 & Hari Plus 1 & 0,0012 & 0,0004 & 0,0000 & 0,0214 & 0,0029 \\
5 & Hari Plus 2 & 0,0011 & 0,0003 & 0,0000 & 0,0417 & 0,0039 \\
\hline \multicolumn{7}{c}{ Panel B. Tahun 2016 } \\
\hline 1 & Hari Minus 2 & 0,0016 & 0,0004 & 0,0000 & 0,0216 & 0,0033 \\
2 & Hari Minus 1 & 0,0016 & 0,0004 & 0,0000 & 0,0257 & 0,0038 \\
3 & Cum-dividend date & 0,0015 & 0,0006 & 0,0000 & 0,0216 & 0,0028 \\
4 & Hari Plus 1 & 0,0012 & 0,0004 & 0,0000 & 0,0216 & 0,0025 \\
5 & Hari Plus 2 & 0,0010 & 0,0004 & 0,0000 & 0,0216 & 0,0025 \\
\hline
\end{tabular}

Sumber: diolah

Nilai median aktivitas perdagangan saham cenderung meningkat menjelang dan saat cum-dividend date, lalu menurun setelah cum-dividend date. Hal ini menyiratkan adanya peningkatan frekuensi saham yang diperdagangkan menjelang dan saat cum-dividend date.

Untuk pengujian normalitas data pada abnormal return untuk tahun 2015 dan 2016, hanya pada hari Plus 1, dimana distribusi data penelitian ditemukan normal. Sedangkan, pada hari-hari yang lain, distribusi data penelitian ditemukan tidak normal. Sedangkan untuk volume perdagangan saham untuk tahun 2015 dan 2016, tidak ada satupun data yang memiliki distribusi normal. Artinya, semua data berdistribusi tidak normal.

\section{Pengujian Ada Tidaknya Abnormal Return}

Pada tahun 2015 ditemukan hanya ada satu hari dimana abnormal return berbeda dari nol. Artinya, pada hari itu, abnormal return diperoleh investor jika membeli saham sebelum hari itu dan menjualnya di hari itu. pada data tahun 2016, dimana dari lima pengamatan, ada tiga hari yang nilai rata-rata abnormal return-nya adalah signifikan (berbeda dari nol). Ketiga hari yang dimaksud adalah hari Minus 2 (positif), Plus 1 (negatif), dan Plus 2 (negatif).

Secara umum, hasil analisis atas ada tidaknya abnormal return menunjukkan ketidak-konsistenan hasil. Rata-rata abnormal return tidak selalu positif di hari cumdividend dan hari-hari menjelang cum-dividend. Demikian juga halnya, rata-rata abnormal return tidak selalu negatif setelah cum-dividend. Namun demikian, setidaknya ada bukti yang mendukung teori dan empiris bahwa pada ex-dividend date, rata-rata abnormal return adalah negatif. 
1. Uji Hipotesis 1

Tabel 3. Hasil Uji Beda Median Abnormal Return

\begin{tabular}{|c|c|c|c|c|c|c|c|c|}
\hline \multirow{2}{*}{ Keterangan } & \multicolumn{2}{|c|}{ M2-CD } & \multicolumn{2}{|c|}{ M1-CD } & \multicolumn{2}{|c|}{ CD-P1 } & \multicolumn{2}{|c|}{ CD-P2 } \\
\hline & M2 & CD & M1 & CD & CD & P1 & CD & P2 \\
\hline \multicolumn{9}{|c|}{ Panel A: Tahun 2015} \\
\hline \multirow[t]{2}{*}{ Median } & 0,0027 & . & - & - & - & 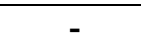 & - & \multirow[t]{2}{*}{0,0004} \\
\hline & & 0,0002 & 0,0005 & 0,0002 & 0,0002 & 0,0068 & 0,0002 & \\
\hline Beda median & \multicolumn{2}{|c|}{0,0025} & \multicolumn{2}{|c|}{$-0,0003$} & \multicolumn{2}{|c|}{$-0,0066$} & \multicolumn{2}{|c|}{$-0,0002$} \\
\hline z-hitung & \multicolumn{2}{|c|}{$-3,949$} & \multicolumn{2}{|c|}{$-4,399$} & \multicolumn{2}{|c|}{$-3,831$} & \multicolumn{2}{|c|}{$-2,653$} \\
\hline p-value & \multicolumn{2}{|c|}{0,000} & \multicolumn{2}{|c|}{0.000} & \multicolumn{2}{|c|}{0.000} & \multicolumn{2}{|c|}{0.008} \\
\hline Kesimpulan & \multicolumn{2}{|c|}{ Ada perbedaan } & \multicolumn{2}{|c|}{ Ada perbedaan } & \multicolumn{2}{|c|}{ Ada perbedaan } & \multicolumn{2}{|c|}{ Ada perbedaan } \\
\hline \multicolumn{9}{|c|}{ Panel B: Tahun 2016} \\
\hline Median & 0,0004 & 0,0006 & 0,0004 & 0,0006 & 0,0006 & 0,0004 & 0,0006 & 0,0004 \\
\hline Beda median & $-0,0$ & 002 & $-0,0$ & 002 & $-0,0$ & 002 & $-0,0$ & 002 \\
\hline z-hitung & -1 & & -0 & 721 & & 57 & & 358 \\
\hline p-value & 0,2 & & 0, & 71 & & 00 & & \\
\hline
\end{tabular}

Kesimpulan Tidak ada beda Tidak ada beda Ada perbedaan Ada perbedaan Sumber: diolah

Keterangan:

M2 adalah hari Minus 2, M1 adalah hari Minus 1, CD adalah hari cum-dividend, P1 adalah hari Plus 1, dan P2 adalah hari Plus 2.

Hasil pengujian hipotesis pertama untuk tahun 2015 menunjukkan adanya perbedaan abnormal return antar pasangan hari. Semua pasangan hari menunjukkan signifkan pada tingkat $99 \%(\alpha=1 \%)$. Artinya, terdapat perbedaan nilai abnormal return antara hari-hari sebelum dan hari cum-dividend dan antara cum-dividend dan hari-hari sesudahnya. Dengan demikian dapat dinyatakan bahwa untuk data tahun 2015 , hipotesis pertama penelitian yang menyatakan abnormal return saham berbeda antara sebelum, saat dan sesudah hari cum-dividend diterima.

Pada tahun 2016 dari empat pasang hari yang diuji, perbedaan signifikan hanya ditemukan pada pasangan hari cum-dividend dengan hari Plus 2 pada tingkat 95\% $(\alpha=5 \%)$. Artinya, terdapat perbedaan nilai abnormal return antara hari cumdividend dan hari Plus 2. Sedangkan tiga pasangan hari yang lain tidak menunjukkan adanya perbedaan yang signifikan. Dengan demikian dapat dinyatakan bahwa untuk data tahun 2016, hipotesis pertama penelitian yang menyatakan Abnormal return saham berbeda antara sebelum, saat dan sesudah hari cum-dividend ditolak. Artinya, tidak ada perbedaan signifikan nilai rata-rata abnormal pada hari sebelum cumdividend dan sesudah cum-dividend. 


\section{Uji Hipotesis 2}

Tabel 4. Hasil Uji Beda Median Trading Volume Activity

\begin{tabular}{|c|c|c|c|c|}
\hline \multirow{2}{*}{ Keterangan } & M2-CD & M1-CD & CD-P1 & CD-P2 \\
\hline & M2 & CD & CD & CD \\
\hline \multicolumn{5}{|c|}{ Panel A: Tahun 2015} \\
\hline Median & $0,0003 \quad 0,0005$ & $0,0004 \quad 0,0005$ & $0,0005 \quad 0,0004$ & $0,0005 \quad 0,0003$ \\
\hline Beda median & $-0,0002$ & $-0,0001$ & $-0,0001$ & $-0,0002$ \\
\hline z-hitung & $-2,439$ & $-0,965$ & $-1,747$ & $-3,266$ \\
\hline p-value & 0,015 & 0,334 & 0,081 & 0,001 \\
\hline Kesimpulan & Ada perbedaan & Tidak ada beda & Tidak ada beda & Ada perbedaan \\
\hline \multicolumn{5}{|c|}{ Panel B: Tahun 2016} \\
\hline Median & $0,0004 \quad 0,0006$ & $0,0004 \quad 0,0006$ & $0,0006 \quad 0,0004$ & $0,0006 \quad 0,0004$ \\
\hline Beda median & $-0,0002$ & $-0,0002$ & $-0,0002$ & $-0,0002$ \\
\hline z-hitung & $-1,759$ & $-1,417$ & $-2,885$ & $-4,152$ \\
\hline $\mathrm{p}$-value & 0,079 & 0,157 & 0,004 & 0,000 \\
\hline Kesimpulan & Tidak ada beda & Tidak ada beda & Ada perbedaan & Ada perbedaan \\
\hline
\end{tabular}

Keterangan:

M2 adalah hari minus dua, M1 adalah hari minus satu, CD adalah hari cum-dividend, P1 adalah hari plus satu, dan P2 adalah hari plus dua.

Hasil pengujian untuk data tahun 2015 menunjukkan ada dua pasang hari yang perbedaan nilai aktivitas volume perdagangan saham secara statistik signifikan dan dua pasangan hari yang tidak signifikan. Perbedaan nilai aktivitas volume perdagangan saham ditemukan signifikan antara pasangan hari Minus 2 dan hari cum-dividend $(p<5 \%)$ dan antara hari cum-dividend dan hari Plus $2(p<1 \%)$. Adapun median nilai aktivitas volume perdagangan saham pasangan hari Minus 1 dengan hari cum-dividend dan pasangan hari cum-dividend dengan hari Plus 1 tidak signifikan. Mengacu pada hasil pengujian, dapat dinyatakan bahwa untuk data tahun 2015, hipotesis penelitian yang menyatakan aktivitas volume perdagangan saham berbeda antara sebelum, saat dan sesudah hari cum-dividend diterima.

Data tahun 2016 dalam hal ini hasil pengujian menunjukkan masing-masing ada dua pasang hari yang perbedaan nilai aktivitas volume perdagangan saham secara statistik signifikan dan tidak signifikan. Perbedaan nilai aktivitas volume perdagangan saham ditemukan signifikan antara pasangan hari cum-dividend dan Plus $1(\mathrm{p}<1 \%)$ dan antara hari cum-dividend dan hari Plus $2(\mathrm{p}<1 \%)$. Adapun median nilai aktivitas volume perdagangan saham pasangan hari Minus 2 dengan hari cum-dividend dan pasangan hari Minus 2 dengan hari cum-dividend tidak signifikan. Mengacu pada hasil pengujian, dapat dinyatakan bahwa untuk data tahun 
2015, hipotesis penelitian yang menyatakan aktivitas volume perdagangan saham berbeda antara sebelum, saat dan sesudah hari cum-dividend diterima.

\section{Perbedaan Abnormal Return Saham}

Hasil pengujian hipotesis menunjukkan bahwa hipotesis penelitian diterima untuk data tahun 2015. Sedangkan untuk data tahun 2016, hipotesis penelitian tidak dapat diterima dengan kata lain adalah ditolak. Artinya, penelitian ini menunjukkan ketidakkonsistenan hasil.

Hasil penelitian untuk data tahun 2015 menarik untuk dicermati. Nilai abnormal return negatif pada hari cum-dividend bagaimanapun berlawanan dengan harapan orang. Namun demikian, bukti adanya abnormal return yang signifikan pada hari cumdividend dan perbedaan abnormal return yang signifikan antar pasangan hari (Tabel 3 Panel A) menyiratkan bahwa pasar modal Indonesia setidaknya belum bisa masuk ke dalam pasar efisien bentuk semikuat (Fama, 1970). Menurut Fama (1970), pasar dikatakan efisien bentuk semi kuat (semi strong), jika kita tidak mungkin untuk memperoleh abnormal return dengan mengandalkan informasi publik.

Pengumuman pembayaran dividen yang didalamnya pasti ada informasi tentang hari cum-dividend dan hari ex-dividend merupakan cermin dari informasi publik. Di sebuah pasar yang efisien bentuk semikuat, informasi publik dan informasi harga saham masa lalu tidak dapat digunakan untuk secara terus menerus memperoleh abnormal return.

Secara umum penelitian ini mendukung teori sinyal dividen. Hal ini membuktikan pemberian dividen atas pengumuman dividen berpengaruh signifikan terhadap harga saham.

\section{Perbedaan Aktivitas Volume Perdagangan Saham}

Sebagaimana ditunjukkan dalam Tabel 4 , antar pasangan hari pada aktivitas volume perdagangan saham tidak selalu memiliki perbedaan yang signifikan, yaitu dua dari empat pasangan untuk masing-masing tahun amatan, penelitian ini tetap menyimpulkan adanya perbedaan. Aktivitas volume perdagangan saham cenderung meningkat menjelang dan saat cum-dividend date, lalu menurun setelah cumdividend date. Ada peningkatan frekuensi saham yang diperdagangkan menjelang dan saat cum-dividend date. Hal ini dapat dimaknai bahwa investor menggunakan cum-dividend date sebagai hari untuk menambah koleksi saham mereka dalam rangka untuk memperoleh dividen. Hal lain yang tersirat terkait dengan peningkatan aktivitas perdagangan saham dan volume perdagangan saham adalah hal tersebut 
dapat dikaitkan dengan fenomena bahwa dividen adalah sesuatu yang pasti. Artinya, investor akan cenderung lebih menyukai dividen daripada capital gain yang merupakan cermin dari teori Bird in the Hand.

Hasil penelitian ini setidaknya mendukung saran dan apa yang dilakukan oleh penelitian sebelumnya tentang pentingnya informasi volume perdagangan sebagai salah satu sumber informasi untuk membeli atau menjual sekuritas.

\section{Kesimpulan}

Investor akan memperoleh abnormal return pada hari-hari di sekitar cumdividend untuk data tahun 2015 dan 2016. Selain itu, terdapat perbedaan abnormal return pada pasangan hari antara hari sebelum dan saat cum-dividend, dan antara hari cum-dividend dan sesudahnya, yaitu pasangan hari Minus1, Minus 2, Plus 1, dan Plus 2. Adapun untuk data tahun 2016, perbedaan abnormal return ditemukan justru pada hari setelah cum-dividend, yaitu pasangan hari Plus 1 dan Plus 2.

Aktivitas volume perdagangan saham pada hari sebelum cum-dividend sampai saat dengan cum-dividend cenderung meningkat, tetapi turun pada hari sesudah cum-dividend. Hasil pengujian ada tidaknya perbedaan tingkat aktivitas volume perdagangan saham menunjukkan terdapat perbedaan yang signifikan untuk masing-masing pasangan hari. Untuk data tahun 2015, perbedaan aktivitas volume perdagangan saham ditemukan pada hari Minus 2 dan hari Plus 2. Sedangkan untuk data tahun 2016, perbedaan ditemukan pada pasangan hari Plus 1 dan Plus 2.

\section{Saran}

Mengacu pada hasil pembahasan dan kesimpulan, saran-saran yang dapat diajukan adalah sebagai berikut: (1) Investor dapat menggunakan perisitiwa pengumuman pembagian saham, yang dalam hal ini adalah cum-dividend sebagai salah satu strategi perdagangan. Hal ini dilakukan mengingat harga saham cenderung berubah menjelang hari cum-dividend dan cenderung turun pada hari sesudahnya; (2) Manajemen perusahaan dapat menggunakan hasil penelitian ini untuk kapan idealnya menetapkan pengumuman dividen jika berharap ada apresiasi baik dalam harga saham maupun aktivitas volume perdagangan saham; (3) Penelitian yang akan datang dapat dilakukan dengan melakukan dua hal. Pertama, mengamati perbedaan abnormal return dan aktivitas volume perdagangan saham dengan membandingkan antar industri (sektor). Kedua, penelitian yang akan datang dapat dillakuan dengan secara khusus memfokuskan pada sampel dengan tingkat 
perdagangan tinggi di sekitar hari cum-dividend untuk secara tegas mengamati saham-saham yang memiliki likuiditas perdagangan tinggi.

\section{Daftar Referensi}

Aharony, J. dan I. Swary, 1980, Quarterly dividends and earnings announcement and stockholders' return: An empirical analysis, Journal of Finance, 35 (1), 1-12.

Fama, E.F. 1970. Efficient Capital markets: A review of theory and empirical work. Journal of Finance, 25(2): 383-417.

Firmansyah, R., dan E.S. Violita. 2007. Analisis pengaruh pengumuman ex-dividend date terhadap abnormal return: Event study pada Bursa Efek Jakarta. IntegrityJurnal Akuntansi dan Keuangan, 1(3): 249-262.

Gumanti, T.A. 2013. Kebijakan Dividen: Teori, Empiris, dan Implikasi, UPP STIM YKPN: Yogyakarta.

Siaputra L. dan Atmadja, A.S. (2006). Pengaruh pengumuman dividen terhadap perubahan harga saham sebelum dan sesudah ex dividend datedi Bursa Efek Jakarta (BEJ). Jurnal Akuntansi dan Keuangan, 8 (1), 71-77.

Sunariyah. 2000. Pengantar Pengetahuan Pasar Modal, Penerbit UPP AMP YKPN, Yogyakarta.

Winarno, A. 2006. Hubungan pengumuman dividen meningkat dengan reaksi pasar modal pada perusahaan manufaktur yang go public di BEJ (Pengujian efisiensi pasar bentuk setengah kuat secara keputusan), Jurnal Ekonomi dan Manajemen, 7 (1), 117-127. 